\title{
Theory and Practice in the Politics of Recognition and Misrecognition
}

\author{
Wendy Martineau $\cdot$ Nasar Meer $\cdot$ Simon Thompson
}

Published online: 7 February 2012

(C) Springer Science+Business Media B.V. 2012

In recent years, the idea of the politics of recognition has become an increasingly popular way of thinking about a wide range of political phenomena, from the logic of social struggles to the nature of social justice. While the provenance of the idea of recognition in social and political theory may be traced to a number of intellectual traditions (Laegaard 2005), the two most prominent contemporary proponents arguably begin their dialogues with the same source (Toppinen 2005). Charles Taylor's essay on 'The Politics of Recognition' (1994) and Axel Honneth's book Kampf um Anerkennung (1992), both widely regarded as landmark texts on the topic, spend some time engaging with-both appropriating and departing fromHegel's philosophical system.

Taylor opens his account by highlighting the way in which contemporary politics has become significantly shaped by the need or demand for recognition made by oppressed or marginalized individuals and groups. He draws on Hegel and Rousseau, amongst others, to give a philosophical and historical account of how the concept of recognition has come to have this wide-ranging resonance, arguing that recognition is not just a courtesy we owe people, but 'a vital human need' (1994, p. 26), one crucial to our ability to become full human agents. This claim stems from the account of the fundamentally dialogical character of human identity which

\footnotetext{
W. Martineau

School of Sociology, Politics and International Studies, University of Bristol, 34 Tyndalls Park Road, Clifton, Bristol BS8 1TY, UK

e-mail: wendymartineau@hotmail.co.uk

N. Meer

School of Arts and Social Sciences, Northumbria University, Lipman Building, Newcastle upon Tyne NE1 8ST, UK

e-mail: Nasar.Meer@northumbria.ac.uk

S. Thompson $(\bowtie)$

Department of Arts, University of the West of England, Frenchay, Bristol BS16 1QY, UK

e-mail: Simon.Thompson@uwe.ac.uk
} 
Taylor had previously elaborated on in Sources of the Self (1989). One can become a self, capable of self-understanding and achieving 'self-definition', only in relation to other conversation partners, within 'webs of interlocution' (Taylor 1989, p. 32, 36). It is only against the background of these webs of interlocution that the self is able to make coherent choices 'about what is good or bad, what is worth doing and what not, what has meaning and importance... and what is trivial and secondary' (Taylor 1989, p. 28). In relation to this framework, we understand ourselves in narrative form. The self is changing and on a 'quest', but there 'is something like an a priori unity of a human life through its whole extent' (Taylor 1989, pp. 51-52).

For Taylor, this requires that the self is able to orientate itself to the good which is provided through access to its community. Furthermore, since our identity is constituted at least in part by our membership of a particular cultural group, an individual's sense of self worth is deeply tied to the value that others attach to this group. If this group is demeaned or held in contempt, then its members will suffer real harm as a consequence (Taylor 1994, p. 25). Taylor explicitly draws on Hegel to argue that 'the struggle for recognition can find only one satisfactory solution, and that is a regime of reciprocal recognition among equals' (1994, p. 50). Asymmetrical relationships such as that of master and slave are unable to provide the recognition necessary for either party to lead a full flourishing human life. Thus for Taylor the implications of this analysis of recognition point to modern democratic polities which extend public recognition to all their citizens. However, since the state is inevitably biased towards the majority culture, a 'difference-blind' and purportedly impartial liberalism is both unequal and inherently assimilative. It is therefore not enough to extend recognition to all as equally worthy of respect, but also as the bearers of specific identities.

Drawing, like Taylor, on Hegel, Honneth also emphasizes the vital role that relations of recognition play in the formation of human identity. Shadowing Hegel's account of the three arenas of recognition (family, civil society and the state), Honneth argues that there are three modes of recognition, which he refers to as love, respect and esteem. Love is the mode of recognition which, all being well, we receive from our small circle of significant others. Respect is that mode which we experience when our fellow citizens regard us as rights-bearing individuals. Esteem is the sort of recognition we enjoy when we are valued for our distinct contributions to society's collective goals. While Honneth argues that a stable and ongoing experience of all three forms of recognition is vital if individuals are to be able to achieve self-realization, love plays a particularly significant role in this account. It is, Honneth claims, 'conceptually and genetically prior' to the need for respect and esteem (1995, p. 107): it provides the model on which our ideas of respect and esteem are based, and it is also the form of recognition we must experience before we can experience respect or esteem.

Honneth anchors the dynamics of recognition and misrecognition within these three modes of recognition, as individuals and groups react against the experience of misrecognition by struggling to achieve the acknowledgement which they believe they deserve. To the extent to which they succeed in achieving the recognition previously denied to them, Honneth argues that their society has achieved moral progress. However, it is important to note that, according to Honneth, it is not 
appropriate to regard the cultural identities of particular groups as appropriate objects of recognition. In contrast to Taylor, who for instance supports Quebec's claim to be recognized as a 'distinct society' within Canada, Honneth believes that while we may acknowledge the contribution of a particular group to the collective good, we should not value that group's identity per se (Fraser and Honneth 2003, pp. 251-252).

These two accounts of recognition, and the influence they have had on debates about recognition over the last two decades, testify to the ways in which the theory and practice of recognition can be complex but express an enduring means of understanding a range of phenomena, including the formation of individual psyches, the dynamics of political struggles, and the nature of moral progress. The articles in this special issue, which were first presented at the international conference on 'The Politics of Misrecognition' convened in Bristol in 2010, take discussions over recognition as their starting point. ${ }^{1}$ The special remit of this conference, however, was to move this forward by exploring its complementary concept of misrecognition. This is a topic which has received surprisingly little concentrated attention to date. Indeed, it is striking that the two leading authors who we have identified here do not spend much time discussing this concept. For Taylor, the concept of misrecognition is a relatively taken-for-granted inversion of recognition. Thus, he argues, 'our identity is partly shaped by the recognition or absence, often by the misrecognition of others' (Taylor 1994, p. 25). Honneth does provide a more sustained elaboration of misrecognition, regarding it as 'the withdrawal of social recognition, in the phenomena of humiliation and disrespect' (Fraser and Honneth 2003, p. 134).

One theme running throughout this special issue is a close engagement with the scope of Honneth's conceptions of recognition and misrecognition, which are explored through contributions which appropriate his work in a wide and varied manner. More specifically, the following set of articles are broadly divided between theoretically focused considerations of the constituent features of Honneth's conception of misrecognition, and its wider 'real-world' application in contexts of statehood and international relations. Beginning with the former, Ikaheimo explores a key strand of Honneth's account-namely recognition as love-tracing it from Aristotle, via Hegel, to contemporary thinkers, before Pilapil deflects the criticism of psychologism made against Honneth through rendering a 'philosophical anthropology' of recognition and an elevation of the notion of personhood. In this theoretical vein, roughly following Honneth's well-known distinction between three modes of recognition, Laitinen proposes that misrecognition may be understood as failing adequately to respond to the person and their normatively significant features, something that can add to Smith and Deranty's register of the ways in which debates on Honneth have structured the theoretical field of possibilities for theories of recognition. Moving to 'real world' cases, Dübgen shows how misrecognition can be utilized in a critique of development aid which

\footnotetext{
1 We gratefully acknowledge the support which this conference received from the Economic and Social Research Council (ESRC) (grant number PTA-026-27-1939) and the Centre for the Study of Ethnicity and Citizenship (CES) and the Department of Politics (now School of Social and Political Studies), University of Bristol.
} 
perpetuates a mode of thinking about the dependence of 'underdeveloped' countries on those that are 'developed', while Heins applies misrecognition to what is called the 'Arab problem' in Israel in order to challenge Honneth's argument that there is no 'fourth' principle of recognition for cultural groups per se, before Staples relates this issue to the problem of statelessness in international relations.

A second theme animating this special collection is the exploration of misrecognition itself; what forms it may take and its potential to illuminate particular experiences of individuals, conceived not as abstract ends but as situated within specific and concrete social contexts. For Dübgen, for example, misrecognition is conceived as a mode of epistemic injustice which limits the ability of the misrecognised to have their knowledge claims heard. Focusing on misrecognition as opposed to recognition concentrates our attention more fully on the questions of who are being misrecognised, and by whom? The hugely complex answers these provoke in turn have a bearing on what kind of recognition is due. While, for some, misrecognition is invoked as the failure to recognize in some way the distinctiveness of persons (see Heins, this issue), for others, the concept is widened to encompass its aspect as a failure to recognize the status of the other as a 'moral equal of a person' (Pilapil, this issue). Thus while for some, the focus is on misrecognition enacted by political institutions and states, others are concerned with how we as persons can and should more appropriately recognise distant others. Here, misrecognition might be understood as a failure of imagination (see Ikaheimo, this issue) which recalls Richard Rorty's analysis of misrecognition as a lack of solidarity.

While he does not himself use the term, on one reading of Rorty, the act of misrecognition can be characterized as an absence of moral imagination in seeing others as like ourselves: we misrecognise others because we fail to see them as being 'like us'. For Rorty, as for Tocqueville, we must recognise something of ourselves in others if we are to feel sympathy for them. Rorty cites Annette Baier, who follows Hume in seeing sympathy as the fundamental moral capacity. The spread of the human rights culture, for example, is not likely to be brought about through rational arguments but through the spread of solidarity; in coming to regard more and more people as being like ourselves, or what Baier calls 'a progress of sentiments' (Rorty 1993, p. 129). Importantly, for Rorty, identifying others as 'one of us', means something smaller and more local than 'one of us human beings' (as opposed to animals, vegetables or machines). Talk of such a thing as our 'essential humanity' can itself be a category of exclusion, or, to use our terms here, a form of misrecognition. The category of human beings has been used to exclude others not seen as fully human, and thus to excuse their 'inhumane' treatment. ${ }^{2}$

Solidarity should thus be seen as a matter of 'imaginative identification with the details of others' lives, rather than a recognition of something antecedently shared' (Rorty 1989, p. 190). It is to be achieved through the power of the imagination. This is not a case of coming up with descriptions which most closely approximate a 'true'

\footnotetext{
${ }^{2}$ Rorty contends that there are three main ways in which 'human' has been used as a category of exclusion. Firstly, classing people as animals, secondly, the man-child distinction, e.g. calling black males 'boy', and thirdly, using 'man' as a synonym for 'human being'. Rorty claims that in Catherine MacKinnon's view, 'for most men, being a woman does not count as a way of being human' (Rorty 1993, p. 114).
} 
reality, but rather is a question of which descriptions of the world and of ourselves are less useful and which are more useful (Rorty 1999, p. 27). This is a task not for rational argument, but rather through appeals to our emotions: to activate our sentiments of pity, compassion and revulsion.

This notion of misrecognition as the absence of an imaginative identification with the other is explored in Heikki Ikaheimo's investigation into the nature of love as a mode of recognition. He hopes to determine whether love is confined to intimate relations between family members, lovers and friends, or whether it can be broader-perhaps even global-in scope. In order to achieve these ends, Ikaheimo begins by tracing the idea of love from Aristotle, through Hegel, to contemporary thinkers. On his account, Aristotle's idea of philia should be understood as a relationship in which one cares for the other unconditionally, which means one wants what is good for them for their own sake. Ikaheimo argues that Hegel is in close agreement with Aristotle. Liebe is one particular form of finding oneself in the other, which is distinguished from other such forms by the presence of the attitude of caring for the other for their own sake rather than for ours. Ikaheimo then turns to Harry Frankfurt's recent work on love. While similar to Aristotle's and Hegel's notions, Frankfurt's conception of love can be directed not only to persons, but to a wide variety of objects including groups, moral ideas and traditions. Here, Ikaheimo argues, Frankfurt goes wrong, since all recognitive attitudes are matters of taking the other as a person, and love is a particular way of doing so, namely by making their happiness part of one's own. In light of this careful analysis, Ikaheimo finally asks if love is necessarily restricted to a close circle of intimately known others or whether it is possible to love strangers, and perhaps even all strangers. His tentative suggestion is that, by use of imagination, a personifying attitude of concern for distant and unknown others is possible. It is possible to imagine others as persons, and thus be concerned about their well-being for their own sake. In other words, we can 'imagine lovingly' those we do not know, even if in sensu stricto, we do not love them. In this sense, at least, love may be globalized.

These themes are echoed in Renante Pilapil's article which explores the notion of misrecognition as the failure to recognize one's moral status as a person. Focusing on what he refers to as the 'philosophical anthropology' of recognition, Pilapil reminds us that Honneth is criticised by Fraser for 'psychologization'-reducing struggles for recognition to demands to have one's psychological needs met. Pilapil seeks to deflect this criticism of Honneth by moving the notion of personhood to the centre of the stage. For him, struggles for recognition are struggles to have one's moral status as a person appropriately acknowledged. Pilapil suggests that with this move it is possible to retain the valuable links between the philosophical anthropology and the moral grammar of struggles for recognition, whilst avoiding the charge of psychologization. In order to make this argument, Pilapil undertakes a careful reconstruction of Honneth's theory of recognition, focusing particular attention on the place and role of intersubjectivity in this theory. In doing so, he demonstrates the important part that the notions of moral-practical identity and personal integrity play in this theory. Personhood, according to Pilapil, is a status accorded to individuals in virtue of their basic nature as persons. More specifically, he focuses on three characteristics that persons possess: they are social beings, who 
possess rationality, and are capable of autonomous action. Each of these three characteristics, Pilapil points out, requires certain psychological resources if they are to be fully realized; and, when any of these three features are violated, the dignity of the victims is violated, and each feels as if they are being treated as less of a person. Crucially, Pilapil then argues, such violation may trigger struggles for recognition which, on his account, must be understood as moral struggles for recognition as persons. After countering criticisms that reliance on the notion of personhood may be essentialist and exclusionary, Pilapil's conclusion is that the value of such a notion is to emphasize the moral rather than psychological dimension of struggles for recognition.

This is followed by Arto Laitinen's examination of two particular aspects of misrecognition. First, placing emphasis on the prefix, he asks how misrecognition is different from recognition. In what sense is it inadequate, deficient or wrong? $\mathrm{He}$ argues that to recognize is to respond adequately to another's claims about their person or features of their person. Thus to misrecognize is to fail adequately to respond to that person and their normatively significant features. Laitinen then spells out the different forms that both adequate and inadequate regard may take, roughly following Honneth's well-known distinction between three modes of recognition, referred to here as concern, respect and esteem. Second, moving the emphasis to the main noun, Laitinen asks how misrecognition is different from other kinds of mistreatment. What is special about this form of injury? Here he suggests that broader and narrower definitions of recognition are possible. According to the former, all forms of mistreatment are instances of misrecognition, whilst, according to the latter, only some forms are. Pointing out the advantages and disadvantages of both the broader and narrower views, Laitinen suggests that the choice between these views is a matter for further investigation. One important implication of Laitinen's account of misrecognition is that this deficient attitude only exists because people are fallible: they make mistakes when deciding how to take and treat others. Developing this thought, he suggests that normative failures of recognition fall into one of three broad categories: total ignorance of relevant reasons to recognize, systematic bias in the application of a principle, or simply a situation-specific blunder. Laitinen draws two important lessons from this analysis of fallibility. First, standards of recognition must be at least minimally objective. This is because, if to misrecognize is to make a mistake, then to recognize must be to get it right, to respond correctly to another's normative claims. Second, assuming that individuals' ability to respond adequately to another's normative claims is less than perfect, then it may be better for them to be guided by democratically created, shared norms than to rely on their own subjective judgment.

Moving beyond Honneth, Smith and Deranty register how the debate between Fraser and Honneth has played an important role in structuring the field of possibilities for theories of recognition for a number of years now. While Fraser argues that a politics of recognition must be supplemented by an equally important politics of redistribution, Honneth believes that a single theory of recognition can be used to analyze all of the phenomena with which they are both concerned. In particular, he suggests, the principle of achievement can illuminate the role of recognition for people's experience of work. For Nicholas Smith and Jean-Philippe 
Deranty, however, such a principle is only relevant to one aspect of work-namely, how a particular type of labour is valued by society at large. For them, it does not take account of a stronger sense in which the quality of the work experience itself is of vital importance for determining whether or not individuals feel appropriately recognized. The first stage of Smith's and Deranty's argument draws on Stephan Voswinkel's distinction between two types of recognition that such activity might receive. Workers enjoy 'appreciation' when the time and effort they put in, and loyalty and long-term commitment they demonstrate, are appropriately acknowledged. But they may receive 'admiration' in virtue of their exceptional individual performances. As Smith and Deranty point out, the problem is that these two modes of recognition may conflict with one another: from the perspective of admiration, qualities such as loyalty and commitment are characteristics of the loser, one who may work 'hard' but does not work 'smart'. Smith and Deranty then focus more closely on the quality of the experience of work, employing Christophe Dejours' psychodynamic model of work. Dejours suggests that working is an activity which bridges the gap between the task set and the desired result. The performance required to bridge this gap may be stressful, risky and even physically harmful; or it may be challenging and yet rewarding. The recognition of this performance can be measured along two axes: along the vertical axis, workers' performance may be appreciated by their managers, and, along the horizontal axis, it may be appreciated by the collective with which they work. In some cases, the latter sort of recognition by co-workers can compensate for a lack of recognition by bosses. Finally, Smith and Deranty consider how this analysis of the recognition of working activity may relate to a politics of recognition. Here their suggestion is that if the valid expectation that one's work is appropriately acknowledged is disappointed, then this may lead to the expression of explicitly political claims.

Turning to international development, in her article Franziska Dübgen discusses how the critics of development aid often argue that it is a form of economic injustice which perpetuates the dependence of 'underdeveloped' countries on those that are 'developed'. She argues that it is vital to understand that such aid is not just a medium of maldistribution but also of misrecognition. Her key claim is that by focusing on misrecognition, it is possible to formulate a cogent critique of development aid, and thus to show how it is possible to rectify its injustices. To make this argument, Dübgen draws on the work of Miranda Fricker and others in order to conceive of misrecognition as an epistemic injustice. In fact, she distinguishes three distinct forms that such an injustice can take. First, 'testimonial injustice' occurs when some knowledge producers are regarded as more authoritative than others in virtue of their higher social status. Second, 'cognitional injustice' can be found when some systems of knowledge production are regarded as of more value than others. Third, 'cultural imperialism' is present when the representations of reality of powerful social groups achieve hegemonic status. Dübgen then discusses the writings of three African intellectuals in order to show why all of them regard development aid as a matter of misrecognition which thus presents an obstacle to global justice. To take just one example, Aminata Traore, a Malian politician and writer, argues that so-called development experts deny the validity of indigenous knowledge, and that this epistemic injustice then helps to 
justify the imposition of aid programmes in a way that humiliates the recipient countries. For Dübgen, the best hope for overcoming the injustices bound up with development aid lies with critical development theory. Noting that some strands with this approach focus on symbolic representation, and others focus on economic exploitation, her conclusion is that the way forward is to build what she calls 'transformative solidarity' by tackling epistemic and economic injustice at the same time.

This is followed by Volker Heins who in his article uses what is called the 'Arab problem' in Israel in order to challenge Honneth's argument that there is no 'fourth' principle of recognition for cultural groups per se. For Heins, Honneth closes down the possibility of a fourth principle, according to which the identities of certain collectives should be recognized, because he makes certain simplifying assumptions about the character of the collectives concerned, and-perhaps even more importantly - about the nature of the community in which they wish to be included. Honneth assumes that the groups in question want to be fully included in the existing political community, and he assumes that this community takes the form of a typical European nation-state. Heins then shows how different things look when neither of these assumptions hold. Israel is 'one state for one and a half peoples on an ill-defined territory with few uncontested international borders' (this volume). He explains how different groups of Arabs under Israeli control are treated very differently, from malign neglect to a form of colonial oppression, and how this leads to various sorts of struggles for a range of forms of inclusion. To be specific, Heins identifies three distinct conceptions of equality at work in these struggles: the desire to assimilate into the dominant Jewish identity, the demand for a bi-national state, and the demand for independent Palestinian statehood. In light of the complexities of this particular case, Heins suggests that three important limitations to Honneth's theory become apparent. First, assuming that struggles for recognition can be harmoniously resolved within a stable political community, Honneth fails to appreciate that the identity of that community itself may be hotly contested, and the forms of inclusion demanded in it may vary widely. Second, Honneth assumes that in such struggles it is easy to distinguish between the perpetrators and victims of injustice. But in Israel we find a case of intense mutual disrespect in which both of the principal parties must bear some responsibility for the injustices committed. Third, Honneth assumes that justice is the only valid political goal. But in the current case, while the formation of Israel may have been just, Palestinian resistance to it may nevertheless be morally justified. Heins's conclusion is that in some cases, where it is impossible to achieve mutual respect between groups, a vitally important objective is to protect people against the consequence of others' disrespect.

In the final article of this special issue, Kelly Staples conducts a critical analysis of Honneth's account of respect as the form of recognition which people enjoy when a state accepts them as members. By examining the problem of statelessness, she suggests that Honneth is unduly optimistic about the state's role in the realization of this form of recognition. As Staples explains, statelessness exists because, although all individuals are promised recognition as persons by the Universal Declaration of Human Rights, it is states that have the power to determine who will be their citizens and enjoy the rights that this status entails. According to the best estimates, 
twelve million people currently lack recognition by any state. Staples begins by discussing Hannah Arendt's pessimistic analysis of statelessness. For Arendt, the stateless have been expelled from humanity, and she can see no clear way in which they can regain inclusion. Staples suggests that Honneth's account of recognition does offer some reasons for thinking that Arendt's analysis is too bleak. By showing how intersubjective recognition may be achieved in relations of love, the implication is that the stateless have not necessarily lost all chance to achieve personhood. She goes on to argue, however, that Honneth is too uncritical of the role that the state plays - or fails to play-in securing individuals' recognition. He suggests that the universality of respect provides stability, predictability and a formal equality which other forms of recognition cannot. But Staples argues that what she calls Honneth's 'normative conception of the state' overlooks the operations of power in the state's determination of membership. In particular, she claims, the state's decisions are always appraisive: membership is given or withheld because of some particular characteristics which an individual or group possesses or lacks. To put it in terms of Honneth's own theory, respect is never independent of esteem. Staples' conclusion is that Honneth needs better to appreciate how the state can act as an obstacle to rather than a facilitator of individuals' achievement of respect.

\section{References}

Fraser, Nancy, and Axel Honneth. 2003. Redistribution or recognition? A political-philosophical exchange. London: Verso.

Honneth, Axel. 1992. Kampf um Anerkennung. Berlin: Berlin.

Honneth, Axel. 1995. The struggle for recognition: The moral grammar of social conflicts. Cambridge: Polity.

Laegaard, Sune. 2005. On the prospects for a liberal theory of recognition. Res Publica 11: 325-348.

Rorty, Richard. 1989. Contingency, irony and solidarity. Cambridge: Cambridge University Press.

Rorty, Richard. 1993. Human rights, rationality and sentimentality. In On human rights: The Oxford amnesty lectures, eds. Stephen Shute, and Susan Hurley, 111-134. New York: Basic Books.

Rorty, Richard. 1999. Philosophy and social hope. London: Penguin Books.

Taylor, Charles. 1989. Sources of the self. Cambridge: Cambridge University Press.

Taylor, Charles. 1994. The politics of recognition. In Multiculturalism and the politics of recognition, ed. Amy Gutmann, 25-73. Princeton: Princeton University Press.

Toppinen, Pilvi. 2005. Critical reflections on social justice and recognition. Res Publica 11: 425-433. 